\title{
ATIVIDADE LEGISLATIVA E POLÍTICA QUILOMBOLA: RURALISTAS E OS PROJETOS NO CONGRESSO NACIONAL ENTRE 1988 A 2020
}

\author{
QUILOMBOLA LEGISLATIVE AND POLITICAL ACTIVITY: RURALISTS AND \\ PROJECTS AT THE NATIONAL CONGRESS BETWEEN 1988-2020
}

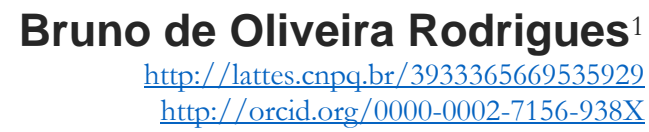

Recebido em 30 de maio de 2020

Aprovado em 27 de agosto de 2020

RESUMO: O presente texto tem como pretensão mapear e filiar a atividade legislativa que tramitou, desde a Constituição Federal de 1988, no Congresso Nacional com a pretensão de regular a questão quilombola. $O$ foco aqui é identificar uma possível filiação ideológica aos projetos e a mobilização de articulação entre os parlamentares em projetos políticos e de poder específicos para a questão quilombola, com isso pretendemos vidraçar a luta dos blocos de poder que se apresentam no campo legiferante federal. Com isso, conseguimos determinar uma certa homogeneidade no campo do poder para a negação dos direitos étnicos-quilombolas pela "bancada ruralista" e, de outro lado, um campo progressista, com protagonismo de partidos de esquerda e centro-progressista.

Palavras-chave: Congresso Nacional; Projeto; Campos de poder; Quilombo;

\begin{abstract}
This text aims to map and affiliate the legislative activity that has been underway since the 1988 Brazilian Constitution in the National Congress with the intention of regulating the issue of "quilombola" (a term that designates the black population with an ex-slave origin). The objective here is to identify a possible ideological affiliation to the projects and the mobilization of the articulation between the parliamentarians in specific political and power projects for the "quilombola" issue, with this we intend to portray the struggle of the power blocks that are presented in the national law in Brazil. With this, we were able to determine a certain homogeneity in the field of power for the denial of ethnic-quilombola rights by the "ruralist bank" (linked to agribusiness) and, on the other hand, a progressive field, with the leading role of the left-wing and center-progressive parties.
\end{abstract}

Keywords: National Congress; Draft; Fields of power; Quilombo;

\footnotetext{
${ }^{1}$ Doutorando em Sociologia e Direito pela Universidade Federal Fluminense (PPGSD/UFF); Mestre em Sociologia pela Universidade Federal Fluminense (PPGS/UFF); Advogado; Membro Pesquisador do Laboratório de Estudos de Movimentos Sociais, Trabalho e Identidade (LEMSTI), do ICHF/UFF; E-mail: brunorodr@gmail.com.
} 


\section{INTRODUÇÃO}

No presente texto pretendemos abordar a temática dos projetos legislativos que tramitaram ou ainda tramitam no Congresso Nacional e que concorrem para produzir marcos normativos para regular a questão do Direito Quilombola no Brasil ${ }^{2}$.

Com isso, pretendemos definir o principal bloco de autores que se alinham para pressionar o Congresso Nacional e incorporar no ordenamento jurídico brasileiro uma percepção neoliberal, marcado por uma máscara liberal, mas que é verdadeiramente conservadora e que pretende dar tratamento ao projeto de proteção da cultura e da gestão das terras no Brasil.

Este escrito, portanto, é uma tentativa de organizar no tempo, entre a promulgação da constituição brasileira vigente (1988), até o presente (2020), os projetos legislativos que concorrem pela atenção do parlamento nos corredores do Congresso Nacional.

Em um primeiro momento apresentaremos as propostas submetidas ao apreço do Congresso Nacional em dois blocos, de um lado aquelas proposituras que tramitaram, ou ainda tramitam, mas que nunca lograram êxito em se consolidar e desenvolver a norma jurídica em sentido estrito, perfectibilizado pelo envio ao presidente, seguido de confirmação pela sanção e publicação em Diário Oficial. De outro lado, em ato sequencial, apresentaremos a tramitação daqueles projetos que ao cabo conseguiram consolidar-se e ser promovidos formalmente a lei em sentido estrito.

Com isso, o leitor verá que a nominação dos agentes políticos demandará um esforço de leitura dos blocos de poder que se apresentam, principalmente aquele que nos permitirá ler a "Bancada Ruralista" enquanto um proto-sujeito que se consolida e mobiliza forças e propostas no Congresso Nacional. Em apresentando o perfil deste sujeito político maximizado, podemos correlacionar os projetos de lei que tramitam ou tramitaram nas casas legiferantes federais na capital brasileira. Creiamos que, com isso, possamos entender e esclarecer os contornos da própria redação e propositura que preenche de moralidade e posição os adereços normativos lá em processo de fabricação.

A teia de sentidos que aqui formulamos pretende, para tanto, passar pela contextualização da questão quilombola no Brasil, sem, contudo, ser o objetivo primordial, sequenciado ainda por um esforço explicativo do desenho daquilo que se convencionou chamar de Bancada Ruralista para, ao cabo, apresentar os projetos de leis que tramitaram no Congresso Nacional entre os anos de 1988 e 2020.

Uma advertência que é apresentada desde o início ao leitor é que o presente artigo não tem como objetivo fazer a exegese do direito quilombola no sistema jurídico, tampouco aprofundar em teoria antropológica para discutir identidade e cultura. Este estudo detém foco na identificação dos atores e na disputa pelo dizer o direito nos corredores do Congresso Nacional. Tampouco é um estudo com rigor epistemológico da Ciência Política, pois não busca travar discussões sobre o campo político no que concerne a demarcação epistemológica de Direita/Esquerda/Centro ou outras categorias.

\footnotetext{
${ }^{2}$ Vale ressaltar que o esforço que aqui produziremos não se confunde com a intenção de explicação e detalhamento do próprio sistema normativo já vigente do Direito Quilombola no Brasil, pois este esforço já realizei no texto "Quilombo e os Direitos: analise da ADIn 3.239 e a luta por dizer o Direito" publicado na Revista Direitos Humanos e Democracia, v. 5, n. 9, 2017. De outro lado, também não é a intenção mapear sobre o esforço dos movimentos sociais para o aparecimento da questão quilombola na grade normativa brasileira, este esforço também já realizei no texto "Movimento Negro e a pauta quilombola no Constituinte: ação, estratégia e repertório", o qual se encontra publicado na Revista Práxis e Direito, v. 10, n. 1, de 2019.
} 
O objetivo primordial aqui, e é o que é a maior novidade deste artigo, é individualizar as dinâmicas e projetos legislativos que são e foram negociados no Congresso Nacional para regulamentar a questão quilombola no Brasil. Com isso, apresentamos um mapa que se presta como fonte de pesquisa para o avanço de outros estudos no campo da temática quilombola no Brasil.

\section{A QUESTÃ̃O QUILOMBOLA NO BRASIL}

Considerando, inicialmente, em termos gerais, os quilombolas enquanto comunidades negras rurais (o que se amplia no tempo e incorpora as categorias de quilombo urbano também), que forjaram identidades étnicas coletivas, com vinculação ancestral e histórica a um passado de opressão, expulsão de seus territórios e de negação de respeito, de reconhecimento, de direitos e, até mesmo, de cidadania.

A gestão de seus destinos e a luta por este reconhecimento enquanto sujeito portador de direitos é fenômenos sociais latente e pulsa nas múltiplas organizações e movimentos que emergem e se consolidam em torno da questão. Estes considerados enquanto processos de luta e resistência, com uma demanda bastante clara que se inicia pela concessão de sua terra enquanto condição do existir e condição para reconhecimento e expansão dos direitos e da dignidade.

Àquilo que chamamos de "questão quilombola" no Brasil foi posta na pauta da Assembleia Nacional Constituinte pelo Movimento Negro que, de acordo com Eliane Cantarino, Sidnei Peres, Alfredo Wagner, João Pacheco, José Maurício Arruti, entre outros, foram absorvidas como pauta ad hoc, principalmente porque a questão ligada ao que hoje chamamos de "quilombolas" estava associada ao movimento campesino (comunidades rurais negras ou campesinato negro rural) e passava longe das pautas de prioridade do Movimento Negro. A preocupação primordial do Movimento Campesino na constituinte era pela reforma agrária, razão a qual a pauta "escanteada" pelo Movimento Campesino naquele momento e foi absorvida pelo Movimento Negro estrategicamente.

Com isto, incorporou-se o direito à terra as comunidades quilombolas na Constituição, inaugurando aí a "questão quilombola", e quando falamos disto não quer dizer que os quilombos nasceram naquele momento, mas tão somente que o feito tratou de incorporar as comunidades quilombolas na agenda do Estado e das políticas públicas, pelo menos enquanto promessa.

A categoria "quilombo", escolhida pelo constituinte inaugurou um espaço de disputa, pois diversas comunidades que nem mesmo se designavam como "quilombos", mas também como terra de santo, bairro de negros, terra de santíssimo, mocambo e outros, como diz Alfredo Wagner $(2004,2011)$. Contudo, estas entenderam que este signo correlato e aproximativo que serviria como instrumento de luta por reconhecimento jurídico, criando a possibilidade de acessar a terra e garantir a sua própria existência: "A identidade quilombola, até então um corpo estranho para estas comunidades rurais negras, passa a significar uma complexa arma nesta batalha desigual pela sobrevivência material e simbólica" (SCHIMITI, TURATTI, CARVALHO, 2002, p. 5).

Assim, a estampa "quilombo" tornou-se objeto de disputa pelo poder de nomeação e significação, principalmente pelos antropólogos e juristas. Ordinariamente os primeiros em um processo de ressignificação e ampliação das margens de significado, enquanto, os segundos 
pelo fechamento terminológico, buscando no próprio Direito um conjunto de signos que mantivessem a segurança jurídica da propriedade, remetendo significação aos sentidos registrados na consulta pretérita de 1740 do monarca Português ao Conselho Ultramarino, frigorificando um conceito no passado e sem relação com o presente das comunidades negras rurais.

O efeito prático foi que se multiplicaram os agentes sociais demandantes dos efeitos e repercussões jurídicas que a configuração quilombola desencadeava, inicialmente o direito à terra e, na sequência, todas as políticas que foram formuladas a partir destes atores sociais.

A constituição consolidou a questão quilombola no art. 68 do Atos das Disposições Constitucionais Transitórias (ADC'T) da Constituição Federal. Contudo, a legislação infraconstitucional passou por um vácuo de marco regulatório até 2001, quando o então presidente Fernando Henrique Cardoso (FHC) editou regulamentação ignorando todo a debate em voga (decreto executivo 3.912), o qual vigorou até 2003, quando o então Presidente Luiz Inácio Lula da Silva (Lula) editou o decreto 4.887, que está vigente até o presente.

O vácuo de regulamentação de 1988 a 2001 não impediu que o Instituto Nacional de Colonização e Reforma Agraria (INCRA) e depois a Fundação Cultural Palmares (FCP) encontrassem formas de aplicar o comando constitucional, começando processos de reconhecimento dos territórios quilombolas e, ainda, emitissem documentos de título para as comunidades, sem quaisquer garantias de efetividade. O fato acirrou o conflito com os latifundiários e setores conservadores, razão a qual o FHC editou o decreto supramencionado, buscando barrar o ativismo da FCP.

O cenário atual é um contexto de mais de 4.000 identidades quilombolas no Brasil já mapeadas, das quais o INCRA contabiliza 1.749 processos de titulação em aberto e que, efetivamente, somente 127 comunidades receberam títulos até então por este órgão. Os dados aumentam para 206 títulos entregues quando se somam os títulos conferidos pelos órgãos estaduais, todos no período entre 1988 a 2018 (último levantamento atualizado). De acordo com dados extraídos do site da FCP, já foram identificadas mais de 3.200 comunidades quilombolas, tendo certificado 2.800. Fica claro que há uma massa de comunidades e uma enorme população que foi abandonada pelo Estado, o qual lhes reconhece a identidade, mas nada faz para viabilizar serviços e recursos que lhes permitam ascender à dignidade. Estes permanecem existindo somente porque da própria existência é difícil abrir mão, assim continuam a sobreviver na e da criatividade do seu fazer/viver, que é marca da resistência dessa classe de atores sociais no Brasil.

Há uma crescente demanda de direitos pelas minorias e, como destaca Knnen, não há instituições legais ou governamentais para que todos reclamem seus direitos e, com isto, a ideia de responsabilidade social passa a ser uma categoria que tem a ver com relações sociais, práticas e éticas, não penetrando enquanto categoria jurídica no universo epistemológico do Direito (2013).

Falando como os economistas, frente a demanda por direitos, estamos preparados para cria-los, e do melhor (ROULAND, 2008, p. 21)!!! Fabricamos diversas declarações sem que se articule quaisquer esforços para implementa-las, disse Knnen (2013, p. 3), enquanto isso, Homi Bahbah ressalta que a história nos apresentou o "nunca mais" ao holocausto, ao escravismo, a colonização, a migração e aos trabalhadores sem terra, contudo, ao mesmo tempo essa mesma memória dizia "no cuenten comigo para hacer lo correcto" (2013, p. 188).

Isto fica bastante nítido quando analisamos sob a ótica orçamentária, onde depois de criar um sistema bastante amplo e extensivo de proteção a identidade quilombola, simplesmente 
esvaziamos os cofres daqueles que devem coloca-las em prática, assim, "conte comigo para fabricar direitos, mas não para empenhar o dinheiro público para atingir o objetivo da lei que criamos".

Em um breve panorama, o INCRA recebeu do orçamento federal, em 2010, o valor de R\$ 32 milhões para os processos de titulação quilombola, o qual chegou a 52 milhões em 2012, depois foi reduzindo paulatinamente, voltando ao patamar de 30 milhões em 2014, 18 milhões em 2015, até os 3.4 milhões em 2019.

Esse esvaziamento dos cofres tem a mesma extensão do vazio compromisso do Estado brasileiro com a proteção, garantia e reconhecimento das identidades étnicas que, em 2019 orçou R 446 milhões para auxílio-moradia para juízes no Brasil, vinte e seis vezes maior que a quantia para garantir o direito das comunidades quilombolas. Ao mesmo tempo, no Programa Enfrentamento ao Racismo e Promoção da Igualdade Racial, em 2016 foram contingenciados 60\% dos valores em relação a anos anteriores, em 2018 nenhum novo recurso foi alocado e, no governo Bolsonaro o contingenciamento chegou a 100\% (INESC, 2019).

A questão quilombola têm, no Brasil, enquanto principal adversário o agronegócio (em sentido expandido), como afirmou Alfredo Wagner em conferência na Conferência 4 da ANPOCS em 2016. Este antagonismo é algo latente, como canalização dos inúmeros conflitos pela terra em todo o Brasil, tanto é que o antigo PFL, hoje Democratas (DEM), moveu uma Ação Direta de Inconstitucionalidade, de número 3.239, em 2004, junto ao Supremo Tribunal Federal (STF), buscando macular todo o marco regulatório infraconstitucional que regula a titulação dos territórios quilombolas no Brasil. Este processo encontrou fim somente em 2018, com a confirmação da constitucionalidade do decreto 4.887 pela corte suprema. Contudo, isso não significa que a luta quilombola venceu, mas tão só que se garantiu a manutenção dos instrumentos legais na luta.

Por outro lado, desde o golpe de 2016, as condições de luta dos quilombolas foram paulatinamente esvaziadas de outro lado, primeiro pela redução seguida de orçamento pelo governo do próprio governo do PT, depois do Temer, chegando até o esvaziamento total dos mecanismos institucionais com o governo Bolsonaro. Este último milita ferozmente contrário as minorias, tendo manifestado publicamente que as minorias devem se adequar as maiorias e que o Estado deve ser exclusivamente para garantia e proteção das maiorias. Exemplo disto é a manifestação presidencial: "Eu fui num quilombo. O afrodescendente mais leve lá pesava sete arrobas. Não fazem nada. Eu acho que nem para procriador ele serve mais. Mais de R\$1 bilhão por ano é gasto com eles"

\section{A PRODUÇÃO LEGISLATIVA NO CONGRESSO NACIONAL}

Pretendemos neste tópico somente destacar as propostas e projetos que pretenderam regular a questão dos direitos quilombolas no Brasil e que tramitaram no Congresso Nacional desde a vigência da Constituição Federal de 1988. O foco aqui é analisar o perfil dos projetos e filiá-los aos grupos de interesse que se articulam.

Neste item serão tratadas as propostas que tramitaram ou tramitam no Congresso Nacional e que não tiveram (ainda) desfecho ou consolidação em norma jurídica, ou seja, nenhuma dessas tornou-se ato normativo vigente, portanto, sem aplicabilidade nenhuma.

Indicamos, desde logo, que aqueles projetos que culminaram em sanção presidencial e foram publicados em Diário Oficial, tornando-se em lei no sentido formal são tratados em item 
apartado no próximo item deste texto. Ainda vale destacar que grande parte dos atos normativos que regulam a questão quilombola no Brasil estão em âmbito administrativo ou são atos regulamentares de origem no executivo, assim, não compõem o eixo analítico proposto aqui, pois tem suas articulações e tramitações fora do Congresso Nacional.

Dito isto, vale ressaltar que o marco legislativo sempre foi, nas questões que envolvem a demarcação e reconhecimento de território étnico no Brasil, alvo de disputas de diversos setores políticos, tanto na questão indígena, quanto quilombola, os seus maiores opositores são sempre os ruralistas, como já se comentou anteriormente. Os olhos dos leitores devem então estar direcionados aos atores políticos e a posição que ocupam nos contextos, pois é o eixo nodal da análise declinada na sequencia.

Em 2017, o "De olho nos ruralistas: Observatório do Agronegócio no Brasil", publicou reportagem de que há, pelo menos, 25 projetos de leis ou de outros tipos de atos normativos que tramitam no Congresso Nacional e que tem objetivo direto atacar os direitos dos povos indígenas e quilombolas. O feito indica uma mobilização organizada de um setor que tem objetivos bastante demarcados e que mobiliza o Congresso Nacional para atingi-los.

$\mathrm{Na}$ questão indígena, muito mais lastreada normativamente e com quantidade de projetos de leis em tramitação, a última guinada legislativa restringiu a dimensão dos direitos indígenas, pois o decreto $22 / 91$ havia trazido avanços em relação a seus predecessores, pois devolveu a competência da regulamentação do território indígena a FUNAI e fixou a coordenação dos grupos de identificação ao antropólogo (ROCHA, 2009,).

O decreto executivo $1.775 / 96$, que revogou o decreto $22 / 91$, foi sancionado pelo então presidente FHC e trouxe, em verdade, maior morosidade ao procedimento de demarcação, pois permitiu o contraditório em qualquer etapa do procedimento de identificação, conforme art. $8^{\circ}$ do referido decreto. A ideia anunciada de que tal instrumento de contestação administrativa iria diminuir a judicialização dos processos de identificação não se concretizou, mas, pelo contrário, prolongou os procedimentos em curso, aumentando o nível dos conflitos locais e de recursos judiciais (ROCHA, 2009, p. 42).

O correspondente ao marco legal indígena no direito quilombola é o decreto 3.912/01, que é contemporâneo decreto 1.775/96, ambos "filhos" do FHC, e detém familiaridades aproximativas, pois são extremamente lacunosos e restritivos aos direitos dos grupos étnicos, não delimitando direitos e só indicando genericamente um direito esvaziado de sujeitos, de materialidade e de procedimentos concretos. Ambos os instrumentos normativos visaram à paralisação dos processos de regulação território étnico e buscavam a redução do tamanho das terras a serem tituladas no país.

A diferença entre estes é que, no caso quilombola, o decreto 4.887/03 do PT substituiu o decreto do PSDB, ampliando sua modulação e detalhando de forma mais minuciosa os direitos a partir de um marco progressista - no caso indígena foi inverso, perdurou uma dimensão restritiva e de negação formal e jurídica de direitos.

A nossa pretensão é detalhar estes com foco exclusivo na questão quilombola, embora se saiba que uma massa de projetos que visam desarticular a questão indígena "respingue" diretamente na questão quilombola.

$\mathrm{Na}$ sequencia pretendemos mostrar o movimento legislativo no Congresso Nacional, focando nas legendas vinculada as proposições e seus conteúdos, pois explicitamente pode-se constatar a mobilização da tecnologia legislativa progressista encabeçadas pelo PT, contraposta a outra restritiva e conservadora dos parlamentares que circulam pelos partidos que 
consideramos conservadores ou de direita ${ }^{3}$.

Nesse esforço, o paradigma indiciário de Carlo Gizburg nos instrumentaliza com um olhar das minúcias, das nuanças e dos detalhes, devemos olhar por trás dos textos, pois eles foram produzidos no tempo e no espaço, enredados em malhas sociais e teias de significados que estão mergulhados em interesses, articulações e pretensões (1987, 1989, 1991, 2012). Mais explicitamente ainda no nosso caso aqui, onde o Congresso Nacional é, por excelência, um espaço de transito e negociação da política.

Como ponto de partida, podemos dizer que antes da Constituição de 1988 o movimento legislativo com foco na questão quilombola é quase que inexistente. No arquivo virtual dos projetos de atos normativos do Congresso Nacional somente verificamos o PL 4733 de 1984, com autoria do Deputado Freitas Nobre, filiado naquela época ao PMDB/SP, com fito de tornar o Quilombo dos Palmares patrimônio Histórico e Artístico Nacional, o que acabou arquivado em 1987.

Contudo, a partir da década de 90, constata-se um movimento legislativo intenso no que se refere a temática quilombola, e é onde se começa a desenhar a articulação da bancada ruralista na questão quilombola. A base da articulação progressista para a proteção dos quilombos é encabeçada pelo PT, depois entra no cenário o PV e PSOL, e, ainda muito timidamente, a REDE e SD. De outro lado, alinham-se aqueles partidos conservadores e de direita, como dissemos, que podemos citar o DEM, PSDB, PPS, PR, PP, PTB e PMDB. Vale destacar a peculiaridade do PMDB, hoje MDB, que pela sua heterogeneidade de composição, que transita da extrema direita até um centro-progressista.

Começando o ano de 1988, durante os trabalhos da Assembleia Nacional Constituinte, a Dep. Benedita da Silva do PT/RJ, apresentou o PL 718, que tinha como objetivo institucionalizar pesquisas para produzir uma historiografia sobre as massas escravizadas, fuga de escravo e crise da escravidão no Brasil. O projeto não tramitou e a autora retirou em 1993.

Depois disso, a atuação e disputa da questão quilombola efetivamente pretendeu disputar espaço no parlamento a partir de 1995, com o impulso da então Sen. Benedita da Silva do PT/RS, que apresentou o PL 129, o qual pretendia criar marco legal para a questão quilombola no Brasil, seu conteúdo é organizado de forma muito aproximada ao decreto 4.887/03, convalidando a sua regulamentação. Este projeto deteve parecer positivo na Comissão de Assuntos Sociais (CAS) pelo então Senador Geraldo Cândido (PT/RJ). Contudo, depois de aprovado nas duas casas, o projeto foi vetado integralmente pelo FHC em 2002, sob alegação de que seria totalmente inconstitucional. Registre-se que o Congresso Nacional não resistiu ao veto.

Após temos a Proposta de Emenda à Constituição (PEC) 190 do ano de 2000, de autoria do então Sen. Lúcio Alcântara do PSDB/CE, o qual pretendia incorporar as disposições do art. $68^{\circ}$ do ADCT no corpo permanente da Constituição, justificando essa alteração dizendo que o direito das comunidades quilombolas de acesso à terra deveria estar no texto da Constituição próximo ao capitulo que dispões sobre direitos territoriais indígenas, estaria então criado o art. 232-A4 . Aqui temos uma máscara progressiva em um esforço conservador, pois na

\footnotetext{
${ }^{3}$ A diferenciação esquerda/direita não funciona no Brasil como posição clara de demarcação, principalmente pela transição dos atores por uma posição de centro que transita pelos dois lados ou que conjuga ideais contraditórios, sem muita explicação de base racional.

4 Art. 232-A. É reconhecido aos remanescentes dos quilombos o direito de propriedade definitiva sobre as terras que ocupam, devendo o Estado emitir-lhe os títulos respectivos, na forma da lei, bem como proteger e fazer respeitar todos os seus bens. (grifo nosso).
} 
transcrição do artigo 68 do ADCT se adiciona ingenuamente o "por lei”, que em termos práticos anularia, naquele tempo, o decreto executivo do FHC que, por óbvio, é ato normativo regulamentar e de origem do Poder Executivo e, portanto, não se confunde com lei. A proposta obteve parecer positivo do Dep. Osmar Serraglio do PMDB/PR na Comissão de Constituição e Justiça e de Cidadania (CCJC) e, em 2009, foi criada uma comissão especial para analisar a matéria, onde lá continua adormecido até o presente. Se fosse hoje aprovado, de forma inversa, reforçaria o decreto 4.887 do Lula.

$\mathrm{O}$ ano de 2003 foi marcado por um movimento normativo que culminou na edição do decreto vigente 4.887, razão a qual diversos movimentos parlamentares relativos a projetos de leis ficaram silenciados nesse período, aguardando a consolidação e formulação do referido decreto. Em 2003, através do decreto executivo sem número, de 13 de maio de 2003, também do Presidente Lula, foi constituído e articulado Grupo de Trabalho Interministerial para rever as disposições do decreto executivo 3.912/01, o qual teve participação da Casa Civil, da Secretaria Nacional de Políticas de Promoção da Igualdade Racial (SEPPIR) e outros ministérios, além da Advocacia-Geral da União e representantes de comunidades quilombolas.

Nesse sentido, o texto do decreto 4.887/03 foi resultado da articulação deste grupo que, consultando diversos setores da sociedade, tais como, especialistas em Direito Agrário, pesquisadores, associações quilombolas, ministérios, procuradorias e lideranças do movimento negro, confeccionaram o texto do decreto. Os setores mais progressistas consideraram o decreto 4.887/03, à época, como uma inovação progressista da tecnologia jurídica, vez que emergiu das bordas de uma ordem jurídica hegemônica, recompondo o direito à voz de setores marginalizados, plantando, dentro da organização do sistema-direito, o grito quilombola (LEITE, 2010).

Depois da edição e vigência do decreto 4.887/03, o movimento do Congresso Nacional reapareceu enquanto cenário de disputa em torno dos direitos culturais.

Mais adiante temos a PEC 161 em 2007, de autoria do Dep. Celso Maldaner do PMDB/SC, que tem como teor claramente obstar a regulamentação dos direitos étnicos via decretos, portarias, instruções normativas, despachos e decisões. O foco era mudar a redação dos artigos constitucionais 225 e 231, no art. 225, inciso III, da CF, pretendia que somente lei poderia criar espaços de preservação ambiental e, de outro lado, mudava também o artigo $231^{\circ}, \int 4^{\circ}$, onde determinava que as terras deveriam ser demarcadas por lei e, ainda, alterava o artigo $68^{\circ}$ do ADCT, também incorporando o signo textual "por lei" no que se refere à emissão dos títulos. Sobre isto a Comissão de Constituição e Justiça deu parecer positivo nos termos do relator Dep. Moreira Mendes do PPS/RO e outro parecer, em separado, desfavorável pelo relator Dep. Luiz Couto do PT/PB. A proposta foi retirada pelo seu autor, mas poderá ser reapresentada a qualquer momento.

Na sequencia temos o Projeto de Decreto Legislativo de Sustação de Atos Normativos do Poder Executivo (PDC) 44 de 2007, de autoria do Dep. Valdir Colatto do PMDB/SC, e tem como objetivo sustar os efeitos do decreto executivo 4.887/03. O projeto teve parecer contrário na CCJC pela relatora Dep. Iriny Lopes do PT/ES, mas teve parecer positivo do Dep. Eduardo Sciarra do DEM/PR na Comissão de Agricultura, Pecuária, Abastecimento e Desenvolvimento Rural (CAPADR), então o projeto foi encaminhado para CCJC, mas foi retirado pelo seu autor.

Temos ainda o PDC 326 em 2007, de também de autoria do Dep. Valdir Colatto do PMDB/SC. Este buscava também sustar os efeitos do decreto executivo 4.883/03, devol- 
vendo a competência da titulação a FCP, ressaltando que só lei poderia mudar competência de um órgão do Estado, pois somente lei poderia mudar outra lei. Este PDC não foi analisado em nenhuma esfera, foi duas vezes arquivado, situação a qual se encontra hoje.

Em nova proposição, o Dep. Valdir Colatto apresentou em 2008 o PL 3.654, que tinha como objetivo regular o 68 do ADCT/CF, em um nítido movimento de substituição do decreto 4.887/03. Textualmente são somente oito artigos, onde se remove o critério de autodeterminação, torna o direito quilombola individual e não coletivo, proíbe a possibilidade de desapropriação e revive a ideia de que o território a ser titulado deve ser aquele efetivamente ocupado e não necessário para sobrevivência ou quaisquer tipos de reprodução. Ainda registra que o artigo 68 do ADCT não seria autoaplicável, ou seja, dependeria de legislação para regulamentação. Este projeto encontra-se arquivado pela mesa diretora, mas que pode ser reapresentado a qualquer momento.

Em 12/07/2011, o Dep. Valdir Colatto do PMDB/SC, mantêm seu protagonismo da resistência ruralista aos direitos quilombolas, apresentou o PL 1836, a qual pretende regulamentar art. 68 do ADCT que reconhece aos remanescentes das comunidades de quilombos a propriedade definitiva das terras que estejam ocupando. O projeto tem oito artigos que, basicamente indica a necessidade do beneficiário (quilombola) comprovar sua condição de remanescente, que as terras estejam em áreas situadas na zona rural, que esteva efetivamente ocupada pelo requerente, sendo ainda vedada a concessão de terra a pessoa jurídica (busca de evitar titulação à Comunidade e atribui-la enquanto direito individual), de outro lado, se traveste de indicações de garantia e proteção a identidade quilombola, dando prioridade na política agrária. Com isso se modula o direito, mas esvazia os sujeitos destinatários. Este projeto recebeu parecer do relator Dep. Josué Bengtson do PTB/PA, em 11/10/2011, na CAPADR, indicando a aprovação. Depois, tramitou pela Comissão de Direitos Humanos, tendo parecer em 26/03/2014 do relator Dep. Henrique Afonso do PV/AC, indicando sua rejeição. Atualmente o projeto encontra-se arquivado.

O Dep. Vicentinho do PT/SP apresentou o PL 3452 em 14/03/2012. Assim como o PL 1836/2011 do Dep. Valdir Colatto, pretendia regular também o art. 68 do ADCT e, ainda, também com somente 8 artigos. Contudo, a proposta do projeto do PT detém inclinação política diametralmente oposta, pois tinha um sentido de apresentar concorrência de projeto político para a mesma matéria ao Congresso Nacional. Este projeto tinha como fundamentação básica lastrear o Decreto 4.887/03, naquele momento questionado sua constitucionalidade por falta de base legal. Então, primordialmente dispõe sobre o reconhecimento e titulação das terras ocupadas por remanescentes das comunidades dos quilombos, estabelecendo a noção de quilombo compatível a vigente no decreto 4887 e, ainda, legitimando todo seu teor. Ele tramitou pela CAPADR em 05/11/2012, recebendo parecer do Relator Dep. Valdir Colatto do PMDB/SC, que indicou rejeição. Contudo, o Dep. Bohn Gass do PT/RS apresentou seu voto em apartado pela aprovação. Após tramitou pela CDHM, tendo recebido parecer do relator Dep. Otoniel Lima do PRB/SP, em 26/02/2014, pela sua aprovação. Depois disso o PL foi arquivado e desarquivado, está então na mesa diretora aguardando andamento.

Percebesse os projetos políticos antagônicos que o PT e o PMDB apresentam para a questão quilombola, já que no mesmo período 2011-2012 ambos apresentaram projetos diametralmente opostos e concorrentes no Congresso Nacional e, além disso, o projeto do PT teve como relator do pmdebista Valdir Colatto que é o autor do projeto concorrente. Outrossim, ambos projetos receberam pareceres positivos dos aliados do campo e negativos dos oposito- 
res. Outro elemento que se constata nesse cenário é o perfil eminentemente conservador da CAPADR e o caráter progressista da CDHM nesse período. Embora essas configurações se alterem pela mudança das legislaturas e divisão dos cargos e do poder no interior do Congresso Nacional.

Ainda em 2012, o Dep. Amauri Teixeira do PT/BA, juntamente com a Dep. Benedita da Silva do PT/RJ, com a Dep. Janete Rocha Pietá do PT/SP, com o Dep. Luiz Alberto do PT/BA, o Dep. Vicentinho do PT/SP e o Dep. Edson Santos do PT/RJ, apresentaram o PL 4620, o qual buscava alterar o art. 49 da Lei no 8.171/91, com o objetivo expressamente como beneficiários de crédito rural as comunidades quilombolas, ribeirinhas e quebradoras de coco babaçu, atingidos por barragens e assentados da reforma agrária. O projeto recebeu parecer na CDHM, em 04/08/2014, do Relator Dep. Luiz Couto (PT-PB), o qual indicou sua aprovação. Após, o projeto tramitou para a CAPADR, tendo recebido, em 05/07/2015, parecer do Relator Dep. Luiz Nishimori (PR-PR), indicando sua integral rejeição. Depois este seguido para a Comissão de Constituição, Justiça e de Cidadania, tendo recebido parecer do relator Dep. Chico Alencar (PSOL-RJ), em 25/04/2018, indicando sua aprovação, contudo, antes da votação, o Dep. Chico Alencar deixou a legislatura, tendo sido designado enquanto relator o Dep. Reinhold Stephanes Junior do PSD/PR, que afirmou sua constitucionalidade e indicou sua aprovação. O PL se encontra ainda na CCJC, mas foi retirado de pauta por acordo, fica aguardando reingressar na pauta para andamento. Vale ressaltar que este projeto tramita a oito anos no Congresso Nacional, tendo sido arquivo por quatro vezes, sendo que a última vez foi em 02/2019, onde tramitou até 10/2019, depois disso permanece sem andamento.

Em 02/2015, a então Dep. Benedita da Silva do PT/RJ, apresentou o PL 124, com idêntica matéria do PL 4620, a qual também era autora. Com isso a mesma apresentou pedido de retirada do PL, o qual foi acatado em 03/2015 pela mesa diretora.

O Dep. Luis Carlos Heinze do PP/RS, apresentou, em 10/2015, o PDC de número 240. Este projeto pretende sustar os efeitos da Portaria no 531/2015 do INCRA que "declara como terras da Comunidade Remanescente de Quilombo Mormaça" no Município de Sertão no Estado do Rio Grande do Sul. O PL tramita inicialmente na CAPADR, e recebe em 05/2016 parecer do Relator Dep. Onyx Lorenzoni do DEM/RS, o qual indica sua aprovação. Contudo, o Dep. Marcon do PT-RS apresenta voto em apartado, registrando sua indicação pela rejeição, depois, ainda na CAPADR, tendo em vista a redesignação da relatoria, o agora relator Dep. Josué Bengtson do PTB-PA, opina em 05/2017 pela aprovação. Atualmente este PDC se encontra arquivado.

O Dep. Aureo Lídio do partido Solidariedade do RJ, apresentou em 09/2017 o PL 8660, o qual pretende aumentar o limite dos recursos para aquisição de alimentos oriundos da agricultura familiar, das comunidades de quilombo e dos grupos indígenas. Este projeto encontrarse na Comissão de Educação e nunca recebeu qualquer outro movimento ou tramitação.

Em 06/2017, o PDC 684 foi submetido pela ela Comissão Parlamentar de Inquérito (CPI), e visava a suspensão do Decreto 4.887/03 até que se investigue fatos irregulares relativos à Fundação Nacional do Índio (FUNAI) e ao INCRA. Este PDC é assinado na CPI pelo Dep. Alceu Moreira do PMDB/RS, tramita pela CCJC, tendo como relator o mesmo deputado, que indica sua aprovação. Depois disso, por inércia na tramitação foi arquivado e, na sequência, foi desarquivado, mas sem tramitação desde fevereiro de 2019.

Em 06/2018, o Dep. Chico Alencar do PSOL do RJ apresentou o PDC 965, que visava sustar os efeitos da resolução no 12/2018 do Conselho Diretor do INCRA, a qual reduzia 
82,3\% o território quilombola de Mesquita em Goiás. Na Comissão de Direitos Humanos e Minorias, o PDC recebeu parecer da relatora Dep. Erika Kokay do PT/DF, que inclinou sua recomendação de aprovação. Este ainda está na mesma comissão, pois ainda não foi apreciado pela mesma, tendo sido retirado de pauta e sem data para apreciação, onde aguarda andamento.

Um bloco de Deputados do PSOL, compostos por Fernanda Melchionna do Rio Grande do Sul, Edmilson Rodrigues do Pará, David Miranda, Marcelo Freixo e Glauber Braga do Rio de Janeiro, Sâmia Bomfim, Ivan Valente e Luiza Erundina de São Paulo, apresentaram, em 03/2020, o Projeto de Decreto Legislativo (PDL) de número 83, que busca sustar os efeitos da Portaria no 45 do FCP, que acabou por extinguir o Comitê Gestor do Parque Memorial Quilombo dos Palmares, a Comissão Permanente de Tomada de Contas Especial, o Comitê de Governança, o Comitê de Dados Abertos, a Comissão Gestora do Plano de Gestão de Logística Sustentável, a Comissão Especial de Inventário e de Desfazimento de Bens e o Comitê de Segurança da Informação. Atualmente este PDL encontra-se na Coordenação de Comissões Permanentes (CCP), aguardando ser encaminhado para análise da Comissão de Cultura e de Constituição e Justiça e de Cidadania.

O PSOL, em 04/2020, apresentou RIC (Requisição de Informação) de número 335/2020, apresentado pela Dep. Talíria Petrone do PSOL/RJ, pela Dep. Fernanda Melchionna do PSOL/RS, pelo Dep. David Miranda do PSOL/RJ, pela Dep. Luiza Erundina do PSOL/SP e pelo Dep. Ivan Valente do PSOL/SP. Esta requisição foi direcionada ao Ministro de Estado Chefe do Gabinete de Segurança Institucional da Presidência da República, General Augusto Heleno, pretendendo ter informações acerca da expulsão de comunidades quilombolas de Alcântara registradas na Resolução n ${ }^{\circ} 11$ de 20 de março de 2020. O RIC recebeu parecer positivo pelo relator Dep. Marcos Pereira (REPUBLIC-SP), assim, foi remetido ao Ministro Chefe do Gabinete Institucional da PR, o qual aguarda resposta.

Recentemente tramita ainda o PL 1.142, apresentado em $03 / 2020$ por vinte e quatro deputados na Câmara dos Deputados, e tem dentro das diversas pretensões de assistência as comunidades étnicas no Brasil, apresentando um Plano Emergencial para Enfrentamento à Covid-19 em sentido ampliado, atingindo tanto as comunidades quilombolas, como indígenas e comunidades tradicionais, destinando recursos próprios para este fim. A composição dos vinte e quatro proponentes equaliza a partir de dezesseis deputados ligados a legenda do PT, quatro ao PSOL, dois ao PSB, um ao PC do B e, ainda e destoando da linha, a Professora Dorinha Seabra Rezende do DEM de Tocantins. Este projeto demanda ainda apreciação do Senado, aguardando, portanto, votação nessa casa.

Numa leitura atenta aos movimentos supramencionados, percebe-se que o campo progressista na questão quilombola é majoritariamente articulado pelo PT e, mais recentemente, pelo PSOL, eventualmente se visualiza alguma outra sigla como o PV ou o SD, contudo, na condição de coadjuvante, reforçando a pauta progressista. Esta guinada progressista é sempre na busca de reforçar os critérios já eleitos e em vigor pelo decreto 4.887/03. Nesse bloco, é Benedita da Silva, com autoria de três das cinco proposituras do PT, enquanto que os projetos do PSOL data de 2018 a 2020, assim como o projeto do SD. O PSOL e o SD submetem temáticas correlatas que influenciam na questão do direito quilombola, mas não tem como teor uma luta focal e continuada.

De outro lado, o PMDB, PP e PSDB protagonizaram a inclinação conservadora da bancada ruralista no Congresso Nacional e, sem dúvida, o Dep. Valdir Colatto foi um dos maiores protagonistas, com cinco proposituras entre 2007 e 2011 e, ainda, autor de duas relatorias com 
parecer negativo em relação aos projetos dos adversários. Em núcleo, os projetos de Valdir Colatto têm como objetivo a reprimenda ao direito quilombola por múltiplas estratégias.

\section{DOS PROJETOS QUE VIRARAM LEI}

No item anterior tratamos do conjunto de proposituras que tramitam no Congresso Nacional desde 1988 sem desfecho, já neste fragmento, buscaremos tratar dos projetos que lograram êxito em se consolidar em legislação, portanto materializaram em atos normativos e ingressaram no sistema jurídico.

Para tanto, aqui a ideia não é analisar detalhadamente a própria legislação, mas a sua tramitação no Congresso Nacional, identificando sua filiação aos campos de disputa parlamentar.

Em 1988, o poder executivo encaminhou PL 549 ao Congresso Nacional, basicamente seu teor é autorizar o poder executivo a criar a FCP. Foi encaminhado as comissões, contudo, foi acordado pelos líderes dos partidos pela tramitação com prioridade deste PL, o qual foi aprovado com a redação do Dep. Carlos Alberto Caó do PDT/RJ, conhecido por ser redator da Lei Caó, que criminaliza o racismo no Brasil.

Em 1996, a Medida Provisória (MPV) 1528 chegou ao Congresso Nacional, originalmente tratava somente da regulamentação de matéria de Direito Tributário, onde regia questões de fiscalização e imputação de tributo sobre a terra (Imposto sobre Propriedade Territorial Rural - ITR). Contudo, no curso da tramitação, a bancada progressista, através do PT, incorporou a desoneração tributária dos territórios ocupados por comunidades remanescentes de quilombo. A tramitação recebeu originariamente o Sen. Jader Barbalho como relator, o qual emite parecer contrário à sua aprovação. Em plenário o debate ocorre entre o Dep. Valdir Collato do PMDB/SC, o Dep. Hélio Rosas do PMDB, o Dep. Hugo Bieh do PDS/SC, o Dep. Alcides Modesto do PT/BA, o Dep. Domingos Dutra do PT/MA (atualmente no PC do B), o Dep. Adão Pretto do PT/RS, o Dep. Eduardo Suplicy do PT/SP e o Sen. Jonas Pinheiro do DEM/MT.

A MPV 1528 então recebe diversas anotações e emendas na Comissão Mista, com um grande debate entre os Dep. Álvaro Gaudêncio do PFL/PB (com origem na ARENA, passou pelo PHS, PSL, PSB, estando hoje no Avante - antigo PT do B), Confúcio Moura do PMDB/RO, Sen. Jonas Pinheiro do PFL/MT, Dep. José Carlos Vieira do PFL/SC (foi antes do PMDB e depois DEM, PR e depois PSD), Dep. Domingo Dutra do PT/MA (desde 2013 mudou para o SD e depois PC do B), Dep. Mario Negromonte do PSDB/BA (tendo passado pelo PMDB, depois PSDB, PPB e no PP desde 2003). Sen. Odacir Soares do PMDB/RO (de origem na ARENA, filiou-se depois no PDS, passando pelo PFL, depois PTB, depois PPS, PMDB), Dep. Mário Negromente do PSDB/BA (atualmente no PP); Dep. Tete Bezerra do PMDB/MT e Valdir Colatto do PMDB/SC.

Nesse ínterim, pode-se verificar um esforço de modulação da MPV 1528 em um projeto compatível com os interesses da bancada ruralista, buscando privilégios para o setor do agronegócio, com uma clara articulação de Valdir Colatto, Jader Barbalho, Odacir Soares e Jonas Pinheiro, entre outros, que transitavam com frequência nas Comissões ligadas aos temas do agronegócio no Congresso Nacional. Contudo, ao cabo, a Lei 9.393 é publicada, ainda em 1996, com um dispositivo tímido citando a desoneração do ITR para os territórios das comunidades quilombolas.

Aqui temos o PL 1946, apresentado por Gilberto Kassab do PFL/SP em 27/10/1999. Este 
tinha como pretensão regular a Tarifa Social de Energia Elétrica e, tangencialmente acabando por inserir às famílias indígenas e quilombolas no CadÚnico, ganhando desconto de 100\% no consumo de energia elétrica de até $50 \mathrm{kwh} / \mathrm{mês}$, o qual o custo deveria ser suportado pela Conta de Desenvolvimento Energético. Primeiro tramitou na CCJC, tendo sido aprovado em 2008, pelo relator Dep. Leonardo Picciani do PMDB, o qual indicou aprovação de substitutivo. Em 2009, em Comissão Especial, recebeu parecer do Dep. Carlos Zarattini do PT de SP pela aprovação do substitutivo da CCJC. Em 2010 foi sancionada e transformou-se na Lei 12.212 .

No ano 2000, o Dep. Paulo Paim apresentou o PL 3198, que tinha como conteúdo discutir uma proposta para o Estatuto da Igualdade Racial, essa proposta tramita por dez anos no Congresso Nacional até conseguir se consolidar na Lei 12.288 de 2010. Na verdade, a tramitação deste PL é um sucedâneo de conversões e debates sequenciais, pois, inicialmente tem como relator o Dep. Reginaldo Germano, contudo, depois com a apresentação do PL 6912 em 2002 do Sen. José Sarney do PMDB/AP, com tema similar, o primeiro é apensado a este segundo, com isto, amplia-se uma polarização e impasses em relação aos seus conteúdos incompatíveis entre si.

Em 2005, o PL 6912/2002, que já tinha apensado o PL 3198/2000, foi apensado e seguiu tramitação no PL 6264 em 2005, apresentado pelo autor do primeiro PL citado, agora Sen. Paulo Paim do PT/RS, onde havia registrado um capítulo que organizava a questão quilombola de forma bem próxima a do decreto 4.887/03, mas que refutado na Câmara dos Deputados. Com isto, ganhou como relator o Dep. Antônio Roberto do PV/MG que, em 2008, apresentou substitutivo e indicou aprovação. Neste mesmo ano, o PL 6264 apensa a si o PL 3654 do Dep. Valdir Colatto por tratar de matéria correlata e, em ato sequencial, passa a ser discutido em plenário e aprovado com texto consolidado pelo relator Dep. Luiz Couto do $\mathrm{PT} / \mathrm{PB}$.

Na versão final publicada no signo da Lei 12.288 em 2010, ficou registrado um leque de condições que impactam a questão quilombola diretamente, tais como a "garantia do direito à saúde, incluindo melhorias nas condições ambientais, no saneamento básico, na segurança alimentar e nutricional e na atenção integral à saúde", conforme se verifica em seu texto, no art. 8, parágrafo único; determina ainda a criação de linhas de pesquisa, inscrito no art. 12; além disso, indica a preservação cultura no art. 18; continua ainda no art. 31, onde transcreve a literalidade do art. 68 do ADCT/CF e; finaliza com a criação de políticas para o desenvolvimento sustentável das comunidades quilombolas.

Em 2003, de autoria do Presidente Lula, a MPV 111 é submetida ao Congresso Nacional, e com esta fica criada a SEPPIR vinculada à Presidência da República. Na sua tramitação recebe como relator o Dep. Daniel Almeida do PC do B/BA, que emite parecer pela aprovação, que é confirmada em plenário sem quaisquer resistências, tornando a lei 10.678. A SEPPIR desempenhou, em sua curta existência, um papel importante na defesa dos direitos das populações e comunidades negras, combatendo a intolerância étnica e religiosa, depois é, em 2015, extinta, sendo reunida no Ministério das Mulheres, da Igualdade Racial, da Juventude e dos Direitos Humanos pela então Presidenta Dilma e, hoje, no governo Bolsonaro, está nas mãos da contraditória Ministra evangélica Damares Alves.

Em 2009, o PL 5665 é submetido pelo então Presidente Lula, instituir a Política Nacional de Assistência Técnica e Extensão Rural para a Agricultura Familiar e Reforma Agrária (PNATER) e, na redação do PL, são inseridas as comunidades quilombolas na política do PNATER. 
Em termos de tramitação, na CCJC é designado o relator o Dep. José Genoíno do PT/SP, que manifesta pela sua aprovação. Depois tramita na Comissão de Finanças e Tributação (CFT), ganhando também parecer positivo do relator Dep. Pedro Eugênio do PT/PE. Daí passa pela Comissão de Meio Ambiente e Desenvolvimento Sustentável (CMADS), com relatoria do Dep. Wandenkolk Gonçalves do PSDB/PA, que indica aprovação, mas com recomendações de alteração. Na sequencia passa pela CAPADR, com relatoria do Dep. Lira Maia do DEM/PA, que recomenda aprovação com o substitutivo recomendado na CMADS. No plenário é amplamente emendado e é aprovado com a redação final do relator Dep. José Genoíno do PT/SP, sendo publicada em 2010 sob o signo da Lei 12.188.

O PL 18, proposto por Maurício Rands do PT de Pernambuco, em 03/02/2011, com a pretensão de fomento para recuperação agroflorestal de áreas degradadas e desapropriadas para famílias assentadas, indígenas e quilombolas. O projeto tramitou pela CAPADR, tendo obtido parecer do relator Dep. Josias Gomes do PT/BA, indicando a aprovação. Depois foi para CMADS, tendo parecer do então relator Dep. Giovani Cherini do PDT/RS, pela aprovação e, por último, tramitou pela CCJC, tendo também relatoria favorável do Dep. Paulo Teixeira do PT/SP. Após, tendo sido aprovado em plenário, foi sancionado pela então Presidenta Dilma e transformado na lei 12.854 em 2013.

Também em 03/06/2011, o Congresso Nacional foi instado pela necessidade de apreciar a MPV 553 da Presidenta Dilma. A MPV não tramitou por nenhuma comissão, tendo enquanto relator no pleno o Dep. Assis do Couto do PT/PR e visa inserir os quilombolas no programa de apoio à conservação ambiental as famílias em situação de extrema pobreza que desenvolvam atividades compatível com a conservação ambiental e que está registrado na lei 11.326 de 2006. A lei 12.512 então altera a lei 11.326 e tramitou no Congresso Nacional diretamente no plenário. É aprovada nos termos do relatório do Dep. Geraldo Simões do PT/BA, vinculado a Comissão Mistas de Planos, Orçamentos Públicos e Fiscalização, o qual rejeitou todas as emendas.

A atividade legislativa no campo conservador é comedida, com projetos de Valdir Colatto e Jader Barbalho do PMDB e, ainda, um projeto do Kassab do PFL, onde a bancada de direita e conservadora atuou em ações de resistência. De outro lado, a atuação da bancada progressista, pela expansão dos direitos étnicos, atuou basicamente pela legenda do PT, seja pela forçosa apreciação das medidas provisórias presidenciais, duas do Lula e uma da Dilma, mas também com projetos de Rands e Paulo Paim. Com isso, o cenário que se desenha é de uma oposição bastante clara na seara parlamentar.

\section{A BANCADA RURALISTA}

Cremos que a leitura desse cenário é uma queda de braço entre uma ala progressista e de expansão dos direitos das minorias e, de outro lado, um bloco de poder que se organiza enquanto "Bancada Ruralista", que é um grupo de interesse que se articula no Congresso Nacional que, embora bastante plurais em relação ao perfil dos atores sociais convergentes, conseguem se unir para fazer resistência à titulação de terras aos grupos étnicos no Brasil por aproximação ideológica pautada naquilo que eles chama de neoliberalismo, mas que, na verdade, conforme registra Boaventura de Sousa Santos, de liberalismo não tem nada, pois as forças que se movem por detrás desse movimento são em verdade características de um velho conservadorismo (SANTOS, 2003, p. 6-9). 
A cosmovisão de uma unidade para a bancada ruralista revitaliza o "homem do campo" (assim autodesignados), que canaliza para um "nós" que visa fortalecer e ampliar os canais de influência com o Estado. Para Castilhos (2012), estes representam uma conversão ideológica quase como um bloco, ainda não homogênea e, complementa Alfredo Wagner B. de Almeida (2016), que se deve incluir nesse bloco o setor do agronegócio de forma ampliada, associando o agropecuário e a agroindústria, além de outros setores adjacentes desse universo.

Este grupo não é uma classe profissional ou fechada em siglas partidárias (embora alguns partidos também apresentem perfis e interesses de alinhamento com a bancada ruralista), pois são advogados, empresários e etc, mas que se articulam ad hoc, o que para Barcelos e Barriel, compõem uma verdadeira pactuação cavalheiresca (2009). "As diversas bancadas de interesse são espaços de articulação que agregam interesses pessoais ou de classe que não são incorporados nos programas partidários" (INESC, 2011).

A bancada ruralista, de acordo com a pesquisa do INESC, configura-se por aqueles políticos (executivo e legislativo) que declararam, ao TSE, fonte de renda agrícola, ou ainda, que demonstram alinhamento político a grupos derivados do setor do agronegócio - este alinhamento foi configurado pelo recebimento de financiamento de campanha por grupos ligados ao agronegócio.

Há uma nítida conexão entre parlamentares da dita bancada ruralista com a concentração de terra no Brasil e proprietários de fazendas/empreendimentos rurais de grande proporção. Esses "homens do campo" estão familiarizados com as práticas de grilagem de terras devolutas e do INCRA; com atos de violência e despejo contra assentados camponeses e grupos étnicos; com desmatamento, principalmente na "Amazônia Legal”, pois vários são donos de madeireiras; utilizando-se de mão-de-obra escrava; com envolvimento nas grandes chacinas no campo e ligação com o assassínio de lideranças dos movimentos sociais e dos grupos étnicos; com crimes ambientais; com a "clientela" ordinária das grandes multas aplicadas pelos órgãos de fiscalização de meio ambiente. Há também uma "estranha” coincidência de propriedades rurais dos políticos ruralistas com os locais identificados com maior incidência de trabalho escravo, de desmatamento e de eliminação de lideranças de movimentos sociais.

No parlamento, os políticos vinculados ao agronegócio ocupam as cadeiras das Comissões com interesse diretamente ligado a política agroindustrial. As vagas nessas comissões são negociadas entre os partidos, e trocadas entre os partidos de acordo com conveniências.

$\mathrm{Na}$ classe dos políticos com "rabo-preso", podemos exemplificar com o grupo de parlamentares financiados pela "Bancada Friboi", que "investiu”, em Goiás, 10 milhões em dois candidatos a governador, 5.3 milhões em 47 candidatos a deputados estaduais e mais 10 milhões para financiamento de campanhas de 55 candidatos a deputados federais e 8 senadores, onde se elegeram 41 e 7 respectivamente (CASTILHO, 2012). Certamente este "investimento" realizado pelo Grupo Friboi deve trazer frutos.

Há, "curiosamente", uma tendência dos políticos ruralistas de todo o território nacional de deterem propriedades e empreendimentos rurais no norte e centro-oeste, assim como no nordeste, respectivamente - são regiões com maior disponibilidade de terras consideradas "desocupadas" pelos órgãos públicos e pelos ruralista 5 , privadas ou não, e com custo de compra ou ocupação baixo. É também o reduto das grilagens, pois é onde o Estado ainda está mais ausente, notoriamente a lei lá não chega, pelo menos não com tanta força. Os políticos do sul e

${ }^{5}$ A maior parte dessas terras consideradas “desocupadas" estão, em verdade, ocupadas por grupos tradicionais, informação essa não ventilada nas análises governamentais. 
sudeste são os que mais se enquadram nesse perfil, pois mesmo com domićlíio eleitoral numa parte do país, detém terras em outros lugares. O Pará é o destino mais procurado de todos, diz Castilhos (2012).

Barcelos e Barrile indicam que a bancada ruralista, mesmo com grandes disputas internas por poder, protagonismo, privilégios e etc., detém potencial para promover grandes crises organizacionais no campo dos interesses, contudo, tende a alinhar-se homogeneamente para defender fronteiras e/ou expandi-las (2009, p. 10).

Em verdade a bancada ruralista é um bloco plural suprapartidário e que é capaz de mobilizar até mesmo o dobro de sua representação nas casas legislativas, determinando, inclusive, a agenda do legislativo. "A rede começa no poder local, nas prefeituras, e se estende até os corredores de Brasília, configurando o que os italianos chamam de partido transversal" (CASTILHOS, 2012, p. 229).

Vale aqui citar a UDR (União Democrática Ruralista), que surge em 1985 e é comandada pelos seus fervorosos fundadores, o pecuarista Ronaldo Caiado, que transitou pelas legendas do PSD, PFL, PPR e voltou para o PFL (hoje DEM) e pelo cafeicultor Plínio Junqueira Júnior (grande fazendeiro paulista) é um grande exemplo de articulação. Essa entidade foi considerada na constituinte como a mais explicita e radical articuladora de interesses, fazendo e buscando legitimar a proteção da terra privada por meio da violência e com intimidação armada aos seus adversários (BARCELOS, BARRIEL, 2009, p. 11-2). Essa entidade é ungida pelos ideais de resistência e paralisação de quaisquer formas de reforma agrária e democratização da terra no Brasil, o que é bastante ilustrativo na medida que é a fonte dos principais projetos que trataremos logo mais.

Nelson Lefait escreve que a UDR, em seu primeiro ano, conseguiu uma poderosa articulação, indo de âmbito regional para âmbito nacional, logrando êxito na comunicação com as mais altas instâncias da república, seu articulador Plínio Junqueira arregimentou o setor agropecuário mais radical contra qualquer projeto de reforma agrária. No primeiro ano, realizando mais de cinco leilões de gado doado pelos seus membros, arrecadando mais de quinze milhões em cada um, os quais foram explicitamente destinados ao financiamento das campanhas de políticos comprometidos com a livre iniciativa e a propriedade privada, os principais herdeiros dessa fortuna foram as candidaturas de Roberto Cardoso Alves do PMDB, de Magno Bacelar do PFL, de Sergio Cardoso de Almeida do PDS, de Roberto Caiado pelo PFL, entre outros.

Nesse mesmo sentido, os objetivos da UDR se alinha a

[...] defesa da livre-iniciativa; apoio a produtores e sua organização junto à opinião pública; defesa do direito de propriedade rural; participação efetiva nas decisões políticas; estabelecimento de 'diálogo franco e de respeito mútuo entre o Governo, os produtores rurais, a Imprensa e a Sociedade como um todo'; promoção, 'por todos os meios ao seu alcance', da eleição de representantes dos associados para cargos legislativos federais, estaduais e municipais, objetivando a defesa dos interesses da Associação e de seus Membros', dar assessoria técnica e jurídica aos seus associados (SIMON, 1998, p. 62).

No primeiro ano, em 1986, a UDR recrutou 5 mil associados, no termino do segundo ano eram entre 136 mil a 230 mil associados e, ainda, pelos dados da Folha de São Paulo, em 1989, eram 358 mil associados (SIMON, 1998, p. 59). Para termos noção da linha ideológica norteadora da entidade, vejamos parte da declaração de Caiado ao jornal “O Estado de São Paulo”, em 23/04/1987: "Para nós, os produtores rurais, governo democrático é aquele que faz o que

PRACS: Revista Eletrônica de Humanidades do Curso de Ciências Sociais da UNIFAP https://periodicos.unifap.br/index.php/pracs ISSN 1984-4352 Macapá, v. 13, n. 2, p. 229-251, jul./dez. 2020 
nós queremos e até impomos, e não o que nos dita normas" (apud SIMON, 1998, p. 78).

A UDR é expressão mais radical da elite latifundiária, que detém raízes no mundo rural marcado pelo conflito. A lógica beligerante da UDR fora endêmica, ainda mais quando analisamos os conflitos fundiários em curso em todo o território nacional: "Lideres comunitários mortos à queima-roupa na porta de suas casas, famílias envenenadas, casas incendiadas, processos criminais com provas forjadas, atentados, prisões injustificadas [...]" (LEITE, 2010, p. 28).

Há uma pulverização de entidades com perfil ruralista no pós-88, a UDR não mais representa uma unidade homogênea ruralista no país, mas é significativa ainda e representa um estereótipo das inclinações conservadoras no Brasil mascaradas de neoliberal.

A bancada ruralista, enquanto ator político no campo funciona como uma armadura política às personalidades, convergindo a um corpo de ações que dá vida a um sujeito político, seus membros são agentes públicos fomentadores da guerra e da conflitualidade no campo, são "[...] arquitetos táticos que operam um rol de ações e decisões conformadas institucionalmente” (BARCELOS, BARRIOS, 2009, p. 21-8).

Entre seus grandes eixos de interesses estão a paralização dos projetos de reforma agrária; desestimulação da agricultura familiar; trancamento das pautas étnicas de titulação de terras; negociação e perdão integral das dívidas dos grandes empreendedores rurais; expansão das terras cultiváveis, com utilização plena das propriedades rurais; inibição da criação de parques de preservação ambiental, principalmente sem indenização; inibição dos direitos dos trabalhadores rurais; entre outras que convergem.

Como formas de atuação formulam discursos para criminalizar os movimentos sociais, tentando desarticulá-los, assim como, boicotar quaisquer tipos de mobilização que vise o acesso do camponês e dos grupos étnicos a terra. Vejamos uma fala nesse sentido: "O autodenominado Movimento dos Trabalhadores Rurais Sem Terra não conta apenas com o dinheiro de nossos impostos para invadir e depredar imóveis rurais, roubando bens neles existentes. Conta também com o incentivo de nosso Supremo Tribunal Federal” (LUCHESÍ, 2009).

A configuração deste grupo de interesse é por indicativos e sua organização é subterrânea, pois há manifesta dificuldade de mapeá-los, já que não manifestam expressamente seu alinhamento com medo de serem estigmatizados e perderem prestígio político e retração em seu colégio eleitoral.

A bancada ruralista é muito ágil e astuta, cede nas matérias que não colidam diretamente com suas pretensões. Mas têm um nítido foco na colonização de postos do Estado, reunindose em torno do signo convergente a uma dita identidade "agro-brasileira".

O poder e representação desses políticos é regional, suas carreiras iniciam-se nas prefeituras, depois nas cadeiras estaduais e, em escalada, alçam a representações nacionais em Brasília. Há ainda outros políticos, ou famílias, que se perpetuam regionalmente em "feudos" distritais por décadas, com repetição e/ou alternância do poder na ordem do mesmo sobrenome, sem nenhuma pretensão de escalada. O poder é passado de pai para filho, para irmãos, esposas e parentes mais próximos, as elites criam as condições sociais ideais para sua reprodução, perpetuando-se no poder. Tal empreendimento faz parte de um modus operandi postural de classe, que age a partir de esquemas mentais e práticos estabelecidos e esperados, é um verdadeiro habitus, nos termos de Bourdieu. Exemplo disso é o perfil do PMDB, que associa os barões locais, sem grande unidade convergente nacional, mas frequentemente também o PP e DEM.

O modus operandi dos ruralistas é a própria "violência tornada louca" (MORIN, 2010), bus- 
cando tornar a violência e as armas o nível ordinário de resolução dos conflitos, descendo esta ao nível das massas, dos movimentos sociais e de qualquer forma de articulação que represente ameaça ao divino direito de propriedade dos latifundiários, seja através de milícias ou de pistoleiros-mercenários especializados em eliminar lideranças de movimentos sociais, em despejar de famílias e assentados camponeses e em ameaçar fiscais do IBAMA e do INCRA. Parece que essa "violência tornada louca" chega ao seu máximo com a guinada extremista bolsonarista de orientação do Estado.

No site "paz no campo", que é um difusor destes ideais, pode-se encontrar uma verdadeira escola cristã que louva a propriedade privada e o capitalismo. Neste o MST é rotulado de criminoso e fadado ao fracasso, os quilombolas enquanto massa de manobra para revolução de classe e raça, os indígenas como fragmentadores da nação e o movimento ambientalista enquanto farsantes que visam implementar o socialismo e igualitarismo. O site é uma verdadeira cátedra de produção de valores conservadores, há desde artigos a livros lá vendidos, todos colocam Plínio Corrêa de Oliveira enquanto herói da luta pelos valores sagrados e cristãos da propriedade privada, tais mandamentos são cegamento replicados por seus seguidores.

Durante a constituinte formulou-se a Frente Ampla Ruralista que existiu informalmente até 1994, contudo, em 1995, instituiu-se enquanto formalmente enquanto Frente Parlamentar da Agricultura (FPA), que passou a existir com cerca de um terço dos parlamentares desde então. Contudo, enquanto articulador político, a FPA enquanto bloco consegue mobilizar metade do efetivo parlamentar em torno de seus projetos e tem, geralmente, atuação silenciosa, através da propositura de atos normativos, pareceres em Comissões no Congresso Nacional e pactuação prévia e subterrâneas das pautas a serem votadas no plenário, as quais convergem para o seu projeto de poder.

Logo depois da promulgação da Constituição, o INCRA titulou doze comunidades quilombolas. Depois a legislação passou essa atribuição a FCP, com fim de apaziguar os conflitos e retardar os processos de titulação, uma vez que esta Fundação não detinha dotação orçamentária específica para operar as desapropriações. A bancada ruralista entendeu assim estar estancando a titulação de terras às comunidades quilombolas. Mesmo assim a FCP iniciou procedimentos de titulação independente de desapropriação e desintrusão dos territórios, titulando mais 12 territórios mesmo sem recursos.

O FHC promulgou então decreto executivo 3.912/01, que antecede o atual decreto executivo 4.887/03. Naquele previam-se características específicas para a titulação das terras quilombolas, estas deveriam estar "[...] ocupadas por quilombos no ano de 1888 [...]" (RIBEIRO, 2010), o que paralisou as titulações entre os anos de 2001 a 2003, para felicidade desse grupo de interesse.

Em 2003, o Presidente Lula promulgou o decreto 4.887, com a “[...] delimitação das terras com base em modos tradicionais de produção e principalmente com respeito a características culturais se traduz em grandes áreas demarcadas, o que gera conflitos com muitos proprietários [...]" (RIBEIRO, 2010), devolvendo ao INCRA a competência e viabilizando, com designação específica, verba para a desapropriação.

A Constituição institucionalizou um conflito que ainda não se conseguiu apaziguar. A batalha entre o campo progressista e um conservador, no campo dos direitos étnicos permanece aberta. 


\section{DOS PARLAMENTARES-VETORES}

Aqui resolvemos abrir uma janela para falar sobre dois atores sociais que transitam pelos corredores do Congresso Nacional que, em verdade, na questão quilombola são atores-vetores, pelos quais as propostas do lado conservador e do lado progressista fluem. Embora tenhamos o sentido da pauta quilombola mais ou menos bem definida o atual MDB e no PT, a temática se materializa no lado conservador do MDB através do Dep. Valdir Colatto e, do lado progressista do PT, pela figura da Dep. Benedita da Silva, ambos são os parlamentares com atuação mais significativa no debate quilombola. Outros candidatos se alinham a temática de um campo ou de outro, mas com atuação muito mais tímida.

O Dep. Valdir Colatto que está no Congresso Nacional a quase 30 anos, sempre como deputado federal, com legislaturas de 1989-1990, 1993-1995, 1995-1999, 2003-2007, 2007 2011, 2015-2019, fiel a legenda do MDB, contudo, somente se elegeu pelo voto em 2011, todo o mandato anterior assumiu enquanto suplente.

Entre 2003 e 2005, enquanto não assumia como suplente, ocupou a Secretaria de Articulação Nacional do Estado de Santa Catarina, a convite do então governador Luiz Henrique Silveira também do MDB. Já no pleito de 2018, ficou como suplente e, fora do parlamento ainda, foi indicado e assumiu em 2019 como chefe do Serviço Florestal Brasileiro (SFB), vinculado ao Ministério da Agricultura, Pecuária e Abastecimento.

Valdir Colatto é um político profissional, com filiação clara em relação ao projeto político de poder ligado ao agronegócio. Durante todas as suas legislaturas sempre esteve vinculado as comissões de CAPADR ou a CMADS. Na sua biografia ainda registra diversas participações em comissões especiais, todas ligadas ao setor do agronegócio, com temáticas vinculadas a defensivos, extinção de terreno de marinha, proibição de impostos sobre insumos, demarcação de terras indígenas, transporte rodoviário de cargas, redução de agrotóxicos e atendimento ao setor agrícola. Ou seja, todas com interesse do setor que representa, buscando fazer lobby e consolidar interesses.

Em 2016 Valdir Colatto foi a favor do impeachment de Dilma Russef, depois votou a favor da MP da grilagem do Presidente Temer. Votou também a favor da PEC que limita o teto dos gastos. Em 2017 é favorável a reforma trabalhista e, no mesmo ano, foi relator do projeto que visa liberar a caça de animais selvagens no Brasil.

Outra coisa interessante é que, na sua declaração de bens ao TSE, para o pleito de 2018, declarou 2.200 hectares em Roraima (RO), é dono também de uma microempresa com nome Agro Planejamento Agropecuário e Consultoria em RO, além de múltiplos terrenos e outros bens, totalizando um patrimônio de 1.7 milhões pelas suas próprias declarações subvalorizadas em relação aos seus bens. O perfil de seu patrimônio o coloca como nitidamente um senhor de terras e que dedica a vida a sua reprodução no campo político, fortalecendo seus pares, tornando-se assim, seu bastião nos espaços de produção política institucional. Uma questão interessante é que seu patrimônio e investimentos estão em RO, enquanto seu domicílio, reduto eleitoral e articulação política é em SC.

Vale destacar o esforço de subnotificação dos valores dos seus bens, como se pretendesse reduzir e esconder a dimensão de sua riqueza, 2.200 hectares são avaliados efetivamente muito além dos cem mil reais como declarado, por exemplo.

De outro lado, no campo progressista, a Dep. Benedita da Silva é a protagonista da resistência quilombola pelos corredores no Congresso Nacional, além das pautas relacionadas de 
forma mais abrangente ao movimento negro e, é, também, uma ativista feminista.

Em sua trajetória de vida, foi empregada doméstica, faxineira e vendedora ambulante. Na década de 70 foi uma das fundadoras do Departamento Feminino da Associação de Moradores do Chapéu-Mangueira, quando começou a estudar e formou-se em auxiliar de enfermagem, daí conseguiu emprego no Hospital e juntou dinheiro para cursar Serviço Social.

Já na sua vida da política institucional, foi vereadora 1983 a 1986 no município do Rio de Janeiro, depois foi Deputada Constituinte entre 1987 a 1991, onde participou da Subcomissão dos Negros, das Populações Indígenas e Minorias e, também, participou da Comissão de Ordem Social e da Comissão dos Direitos e Garantias do Homem e da Mulher, depois se reelegeu em 1990 a 1994. Depois foi a primeira senadora negra eleita no Brasil, pelo Estado do Rio de Janeiro no período de 1995 a 1998.

Foi vice-governadora pelo Estado do Rio de Janeiro no período de 1999 a 2002, tendo assumido, com a renúncia de Garotinho em 2002, a cadeira de governadora do Rio de Janeiro.

Já no Governo do Presidente Lula foi Secretária de Estado de Assistência Social e Direitos Humanos entre os anos de 2003 e 2004 e foi, em 2007, Secretária de Estado de Assistência Social e Direitos Humanos no governo Sérgio Cabral Filho. Depois disso, foi Deputada Federal nas legislaturas 2011-2015, 2015-2019 e, inclusive, na atual 2019-2023. Sua trajetória no espaço político institucional tem mais de trinta e cinco anos, sempre vinculada ao PT.

$\mathrm{Na}$ sua trajetória no Congresso Nacional transitou pela Comissão da Cultura, pela Comissão da Defesa do Direito das Mulheres, pela Comissão de Seguridade Social e Família e outras.

Para não fazer injustiça, e preservar equidade analítica, Benedita da Silva declarou ao TSE, em 2018, 1.1 milhões de reais de patrimônio, sendo um carro, um apartamento, uma sala e uma fração de outro apartamento e diversos investimentos em aplicações bancários.

Os dois parlamentares são uma classe de agentes políticos fieis as legendas partidárias as quais estão filiados, suas vidas públicas estão ligadas as agendas políticas de seus partidos. Enquanto temos de um lado o Partido dos Trabalhadores vinculado a pautas progressistas e democráticas que visa a população trabalhadora e o combate a pobreza e, de outro lado, o PMDB, que mudou a legenda para MDB, buscando resgatar seu passado contrária a Ditadura, com um modelo de política conservadora, mas com interesses multivocais pela sua característica fragmentaria no campo da direita.

O projeto de poder do MDB é continuar compondo essa grande base chamada "centrão", que se movimenta aderindo a pautas neoliberais e conservadoras, confundindo-se com a direita moderada, mas bastante tolerante e permeável as demandas da direita radical.

$\mathrm{O} \mathrm{MDB}$ se contenta em compor a base dos governos eleitos, numa condição de coadjuvante eterno, contentando-se pela negociação de cargos em troca dos votos que controla no Congresso Nacional, não detendo um projeto nacional e ideológico, pois sua configuração estrutural é um consórcio de forças regionais autônomas, que não se constrange por escandalos ou corrupção de seus partidários, tornando-o agente coadjuvante mais bem-sucedido das américas.

O MDB prefere, portanto, atuar no modelo de presidencialismo multipartidário somente no domínio legislativos, sem, contudo, apresentar candidatos na disputa majoritária, até mesmo porque não consegue consolidar nomes com força para ganhar uma eleição majoritária pelo voto, no máximo, em troca de seu apoio parlamentar, ocupa postos na vice-presidência. 


\section{CONSIDERAÇÕES FINAIS}

Conseguimos perceber que, embora a disputa no parlamento é sempre um lócus de disputa entre políticas ideológicas e projetos de poder, há marés que estas se intensificam a partir de outros elementos de disputa no campo.

No caso da questão quilombola, percebemos que há uma polarização bastante nítida no campo da direita conservadora e de direita e, de outro lado, do centro progressista e esquerda. Sabemos que estas categorias invocam um debate profundo de posição dos agentes políticos no Campo do Congresso Nacional, mas que não foi o objetivo específico aqui.

De outro lado, percebemos que o debate dos direitos culturais no campo da política quilombola se deu polarizado principalmente pelo MDB, com apoio periférico do DEM, PSDB, PPS, PR, PP e PTB. E quando se fala de protagonismo nessa seara específica, não estamos dizendo que o MDB é o maior refratário dos direitos étnicos no Brasil, pois o PP e o DEM são fortes opositores quando se trata de Direito Indígena e direito das comunidades tradicionais, principalmente quando se trata de questão relacionado ao direito Ambiental com ligação direta aos direitos culturais. Indicamos que o DEM é o autor da ADIn 3.239, que visou atacar na seara jurídica o sistema de proteção legislativa da política quilombola, contudo, não se apresenta na seara legislativa como um vetor na formulação de novos atos normativos. Nos parece que há uma notória divisão social do trabalho na guerra contra os direitos étnicos no Congresso Nacional, onde os projetos são focalizados a partir de atores e legendas. No campo progressista, onde o PT, através da militância da Dep. Benedita da Silva, reúne em torno de suas propostas a adesão de outros partidos do campo de esquerda e, até mesmo, de um centro progressista. Nesse sentido, o PSOL, a REDE e o Solidariedade convergem para ratificar tais projetos e, eventualmente, propõem alguma atividade nesse campo. Estes partidos são também protagonistas da defesa de direitos culturais vinculados a outros grupos como os indígenas e demais comunidades tradicionais.

Atualmente a atividade ruralista em resistência aos quilombolas "esfriou" no Congresso Nacional, pois Valdir Colatto não mais detém legislatura. Isso não significa que os ruralistas esqueceram os quilombolas e os direitos culturais, mas tão somente está focado em demandas emergentes ou latentes em outro campo de seu interesse. Somente estão aguardando outro bastião ou a irrupção de uma demanda ardente para apressar suas enormes presas sobre a lebre dos direitos culturais.

Cremos que a ineditude do presente texto, e a sua contribuição para o campo epistemológico, está em consolidar um universo próprio de mobilização e articulação parlamentar em torno da produção legislativa do direito quilombola. E pensamos que serve a pretensão de subsidiar outros estudos e cruzamento de dados em pesquisas transversais relacionados a outros grupos e esferas pontuais de disputa no campo do poder e dos direitos culturais no Brasil e, ainda, para estudos relacionados ao racismo institucional.

\section{REFERÊNCIAS}

ALMEIDA, Alfredo Wagner Berno de. Medo de compreender? Ampliação da ação conservadora em domínios que os pensadores críticos imaginavam ter exclusividade. In: $40^{\circ}$ Encontro Anual da Associação Nacional de Pós-Graduação e Pesquisa em Ciências Sociais, 2016. 
Terras tradicionalmente ocupadas: processos de territorialização e movimentos sociais, In: Revista de Estudos Urbanos e Regionais, Vol. 6, n 1, 2004.

Quilombos e as novas etnias. Manaus: UEA Edições, 2011.

BHABHA, Homi K. Nuevas minorias, nuenos derechos, Buenos Aires: Siglo Veintiuno Editores, 2013.

BRASIL, Ação Direta de Inconstitucionalidade no $\mathbf{n}^{\mathbf{3 2 3 9}}$, de 25 de junho de 2004 - Visa tornar inconstitucional o decreto 4.778/03, de autoria do partido político "Democratas", com tramite no Supremo Tribunal Federal.

BRASIL, Câmara dos Deputados, Fichas de Tramitação. Disponível em: <www.camara.leg.br>.

Constituição Federal, de 05 de outubro de 1988.

Decreto executivo $\mathbf{n}^{\mathbf{0}} \mathbf{3 . 9 1 2}$, de 10 de setembro de 2001 - Legislação ab-rogada pelo Decreto 4887/03.

Decreto Executivo no 4887 de 20 de novembro de 2003. Dispõe sobre o direito das Comunidades Remanescentes Quilombolas.

FCP - Fundação Cultural Palmares. Certificação Quilombola. Disponível em: <http:// www.palmares.gov.br/?page_id=37551>. Acessado em: 24/05/2020.

FPA - Frente Parlamentar da Agricultura. Página principal. Disponível em: $<$ https://fpagropecuaria.org.br/>.

GINZBURG, Carlo. História Noturna. São Paulo: Companhia de Bolso, 2012.

$\mathrm{O}$ queijo e os vermes: $\mathrm{O}$ cotidiano e as ideias de um moleiro perseguido pela Inquisição. São Paulo: Companhia das Letras, 1987.

CASTELNUOVO, Enrico. PONI, Carlos. A micro-história e outros ensaios. Lisboa: Editora Difel e Rio de Janeiro: Editora Bertrand Brasil, 1991. tras, 1989.

Emblemas, mitos e sinais: morfologia e história. São Paulo: Companhia das Le-

INCRA - Instituto Nacional de Colonização e Reforma Agrária. Acompanhamento de processos de Regularização Quilombola. Disponível em: <http://www.incra.gov.br/sites/default/files/incra-andamentoprocessos-quilombolas_quadrogeral.pdf $>$. Acessado em: 25 de maio de 2020.

INCRA - Instituto Nacional de Colonização e Reforma Agrária. Relação de processos de regularização abertos no Incra. Disponível em: < http://www.incra.gov.br/sites/default/ files/incra-processosabertos-quilombolas-v2.pdf>. Acessado em: 25 de maio de 2020.

INESC - Instituto de Estudos Socioeconômicos. Orçamento público e direitos quilombolas, 2019. <https://www.inesc.org.br/orcamento-publico-e-direitos-quilombolas/>. Acessado em: 27 de maio de 2020.

KNEEN, Brewster. La tiranía de los derechos. Itanzaigó: Editorial Cienflores, 2013. LEFAIT, Nelson. O lobby do latifundiário: acusados de montarem milícias particulares, os produtores rurais agora agem à luz do dia no jogo político da UDR. In: Periódico Senhor, São Paulo, 1986. Disponível em <http://www.arqanalagoa.ufscar.br/pdf/recortes/R01937. pdf $>$.

LEITE, Ilka Boaventura; Humanidades insurgentes: Conflitos e criminalização dos quilombos. In: ALMEIDA, Alfredo Berno de, LEITE, Ilka Boventura, O`DWYER, Eliane Cantarino, Et Al, Cadernos de debates Nova Cartografia Social: Territórios Quilombolas e Conflitos, Manaus: Projeto Nova Cartografia Social/UEA Edições, 2010, 
p. $17-40$.

LUCHESÍ, Fabio de Oliveira, O MST e o STF (Tendências/Debates), 2009. Disponível em: <www.udr.org.br>

MORIN, Edgar, Para onde vai o mundo?, Petrópolis: Editora Vozes, 2010.

PODER 360. Declaração de bens dos candidatos. Disponível em < https:/ / eleicoes.poder 360.com.br>. Acessado em: 25 de maio de 2020.

RIBEIRO, Ivana de Pinho. Estado, quilombolas e ruralistas, 2010. Disponível em: <www.alasru.org/wp-content/uploads/2011/09/GT-15-Ivana-de-Pinho-Ribeiro.pdf>

ROCHA, Cláudia Facuri. A Demarcação de Terras Indígenas e o Decreto 17775/96. Dissertação de Mestrado apresentada no Programa de Pós-Graduação em Sociologia e Direito (PPGSD) da Universidade Federal Fluminense (UFF), 2009.

ROULAND, Norbert. Nos confins do Direito. Ed. 2, São Paulo: Martins Fontes, 2008.

SANCHEZ, Isabela. Bancada ruralista já propôs 25 Projetos de Lei que ameaçam demarcação de terras indígenas e quilombolas. In: De olho nos ruralistas: observatório do agronegócio no Brasil, 2017. Disponível em: <https://deolhonosruralistas.com.br/2017/09/11/bancada-ruralista-ja-propos-25-projetos-de-lei-que-ameacam-demarcacao-de-terras-indigenas-equilombolas $>$. Acessado em 24 de maio de 2020.

SANTOS, Boaventura de Sousa. Poderá o Direito ser emancipatório?. In: Revista Crítica de Ciências Sociais, n. 65, maio, 2003.

SCHIMITI; Alessandra, TURATTI, Maria Cecília Manzoli, CARVALHO, Maria Cecília Pereira de, $\mathbf{A}$ atualização do conceito de quilombo: identidade e território nas definições teóricas, In: Revista Ambiente \& Sociedade, Ano 5, no 10, $1^{\circ}$ Semestre, 2002, p. 1-8.

SIMON, Cristiano Gustavo Biazzo. Os campos dos senhores: UDR e elite rural 1985/1988, Londrina: Editora UEL, 1998.

VERDUM, Ricardo. Território quilombola, terra de direito, In: Orçamento e política ambiental, Brasília: INESC, Ano X, Ed. 26, 2011. Disponível em: <www.academia.edu/ 4856023/Territorio_Quilombola_terra_de_direito>. 